\title{
Children's experience of holiness in health care. Are we rendering effective spiritual care?
}

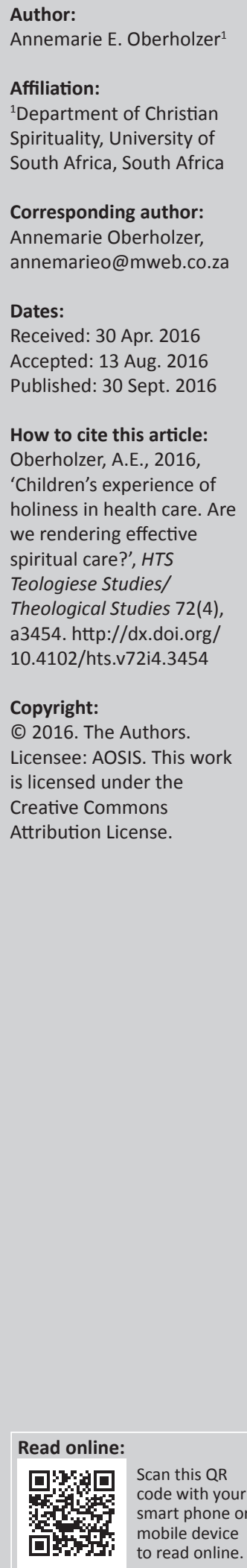

Children themselves place a high value on their own spiritual care when in hospital. However, the spiritual care of children in hospital is often overlooked. Hospitalisation and medical procedures can be traumatic and overwhelming for children, they often see hospitalisation as punishment for something they did wrong and they can even experience spiritual distress during illness and suffering. The spiritual care of hospitalised children should thus be a priority to help these children making sense of pain and suffering, and assisting them to connect with a loving and forgiving God. Spirituality namely influences a diverse range of human concerns such as beliefs about illness and health, fears, relationships with family and friends and the experience of pain and suffering. Unfortunately, children often harbour misconceptions precisely in these areas. This article will draw directly on the given that children are concrete thinkers, yet able to have an understanding of holiness and God as the Holy One, if they receive the right guidance. The study will explore children's spirituality and the way in which they experience holiness in the healthcare environment from a nursing science perspective.

\section{Introduction}

It might seem as if 'Holiness' has got nothing in common with 'Health care', except maybe the first letter. Holiness can be defined as '... a state of being pure, being good, and being loved by God ... being set apart or to be dedicated for special use' (Osinoiki 2016:1). Health care on the other hand might create images of busy hospital wards where medical personnel are hurriedly performing numerous clinical procedures. However, children can easily get lost in the hustle and bustle of medical care. Hospitalisation and medical procedures can be traumatic and overwhelming for children, and they often see hospitalisation as punishment for something they did wrong (Pearson 2005:10-13). Children can even experience spiritual distress during illness and suffering, defined by Clutter (2005:364) as a '... loss of meaning and purpose in life, a diminished sense of love and relatedness, and a lack of forgiveness'. The spiritual care of hospitalised children should thus be a priority to help these children making sense of pain and suffering, and assisting them to connect with a loving and forgiving God.

When conducting research for my doctoral degree, I held interviews with children who were repeatedly admitted to hospital for a life-threatening diagnosis and asked them to rate 19 resources according to their importance for the children. The need for spiritual care was collectively rated as the fourth priority (Oberholzer et al. 2011:5). It is therefore clear that children themselves place a high value on their own spiritual care when in hospital. After having interviews with children diagnosed with cancer, Spilka, Zwartjes and Zwartjes (1991:303) remarks that '... religion could thus act as a protective-defensive system that motivates efforts to cope actively and constructively with the crisis of childhood cancer'. Barnes et al. (2000:900) also agree that religion provides a child with a structure that encourages positive coping strategies and Kamper, Van Cleve and Savedra (2010:302) found that the majority of the children, who took part in their study, rely on God or a higher power to cope with the stress of a cancer diagnosis. Nash, Darby and Nash (2015) give an overview on spiritual care for hospitalised children, stating that:

\footnotetext{
... spiritual care involves helping children and young people by using interpretive spiritual encounters to discuss the difficult and complex aspects of the journey, as well as the more positive points of meaning and connection to be found along the way. (p. 13)
}

Children are capable of significant spiritual experiences (Hart 2003:1) and based on the New Testament stories of Jesus' interactions with and teachings about children, Mercer (2005:23) mentions that children possess 'spiritual capital', giving them power and influence on congregational life. 
Unfortunately, children are not always seen this way and are often excluded and treated with disrespect in congregations (Mercer 2005:24). Mountain (2011:261) adds that Christian theology for many years has been indifferent towards children and Berryman (2009:32) agrees, blaming the predominantly male theologians throughout history for this and speculating that ' ... the development of the de facto doctrine of children would have been very different if woman had been involved in the official discussion from the beginning'.

This same indifference is also evident when considering the spiritual care of children in hospital. I have often encountered visitors in the children's wards, praying for the children, but because the wording of these prayers was aimed for the ears of the adults around the bed, it turned out to be confusing for the children and often led to misconceptions, as will be discussed later in this article. Alternatively, volunteers and church groups relinquish prayer, or any other spiritual support for that matter, in favour of simply playing with children and handing out toys and sweets.

There is a general agreement that the spiritual care of children in health care is a much neglected area (Farrel et al. 2008:262; Feudtner, Haney \& Dimmers 2003:67; Nash et al. 2015:13). Through this article, I hope to enhance the understanding of children's spirituality and broaden the insight into the way in which children experience holiness in the healthcare environment. The study will explore these phenomena from a nursing science perspective, reviewing available literature as well as include illustrative vignettes from the author's own experience as a registered nurse.

Referring to Mark 9:39, Gundry-Volf (2001:44) states that, '... not only is welcoming children a mark of the great; it is a mark of welcoming Jesus himself and, by implication, his divine Sender'.

\section{Children's experience of holiness and God as the Holy One}

It is important to first clarify the difference between spirituality and religion. Although some authors use the terms interchangeably, it is not the same. In a previous article (Oberholzer 2016:5), spirituality is compared to an empty vessel, '... signifying a deep longing to connect with God' in order to give meaning and purpose to our lives, where religion is seen as one of the means through which we connect with God to fill this empty vessel and meet our spiritual needs. Pretorius $(2008: 149$, 151) distinguishes between a religious experience (regarded as the belief in the sacred as expressed through religious rituals and symbols) and a spiritual experience ('a personal, meaningful self-transcendence in a search for the sacred or the inner self'), but in both cases stresses the importance of personal beliefs and perceptions on the experience.

Scarlett (2006:28) describes children as having '... a natural wisdom and capacity for discerning "the way things really are," and a spirituality that comes from being "old souls"' and states further that children should be encouraged and supported to gain from their own spiritual encounters so that they are able to develop spiritually. Nye (2004:93-94) identifies 'relational consciousness' as the main characteristic of children's spirituality, and further explains that children have a natural tendency to have meaningful spiritual experiences that are not linked to their religious and moral understanding. Scarlet (2006) explains that a spiritual experience:

... . requires at least the cognitive ability to step back and 'be aware' - of the larger picture, of the mystery of life, of there being something more than what is given by the senses. (p. 28)

It can therefore be said that children are spiritual beings, capable of spiritual knowing, and able to have a significant experience of and a relationship with God as the Holy One. Scarlett (2006:28) confirms this and refers to a movement opposing theories of stage-structured spiritual development in children, called the Spiritual Child Movement. This opposition is mainly against the developmental stages as proposed by Jean Piaget in the 1950s. Flavell (1963), who translated and interpreted the work of Jean Piaget on the cognitive development of children, states that Piaget came to the conclusion that children under the age of 11 are not capable of abstract thoughts and are:

... unable to discriminate clearly between psychological and physical events; human experiences (thoughts, feelings, wishes etc.) constantly interpenetrate and get confused with the objective reality on which these experiences bear. (p. 281)

Hart (2003:91) states that Piaget '... was both right and also quite wrong or, at least, incomplete' and further argues that children may not be capable of adult logic and reasoning, but they can often have an innate understanding about the core of an issue. Farrel et al. (2008:262) do not agree that the cognitive development of children is prohibiting them from understanding any spiritual concepts and Baring (2012:279) questions Piaget's claim that children cannot conceive God. Johnson and Boyatzis (2006:211) also acknowledges that they differ from the traditional Piagetian view and explain that children have equal abilities to consider both the natural and the supernatural. William James (1902:83) describes spiritual experience as possessing the object of faith as a certainty that is not related to what the intellect regards as real. It can therefore be concluded from the above that cognitive development is irrelevant when considering the spiritual experience of children, and that children can experience God without having an understanding of Him.

Piaget, in the foreword of the book written by Flavell (1963:vii), admitted that he (Piaget) was a naturalist and biologists who never undertook any formal study in psychology, but only focussed his research on the way in which knowledge are acquired. Berryman (1991:139) affirms this in stating that Piaget never claimed to study all kinds of 
thought processes in children, but that he concentrated only on the development of scientific thinking. It is undeniable that Piaget made a valuable contribution in the field of psychology, and his stages of cognitive development are applied widely and respected in understanding the process that children go through to acquire knowledge, but it seems to be unrelated to spirituality.

It can further be argued that, even though children can have significant spiritual experiences that are not related to their intellectual understanding, their intellectual understanding plays a role in the way that they understand religious practices and interpret who God is. McSherry and Smith (2007:17) explain that a child's cognitive developmental level will influence their anxieties, thoughts and imagination that will be utilised, together with certain religious beliefs, to interpret experiences such as illness and hospitalisation. Therefore, if children are not guided in their spiritual experience of God, it can lead to a number of misconceptions especially in a strange and often hostile environment such as the hospital. According to Clutter (2005:368), adults can influence the way children see God, and this can include viewing God as angry at them or even as weak and unreliable.

It is therefore important to also consider the development of children where spirituality is concerned, and for this purpose, the faith development theory as proposed by James Fowler in the 1980s will be discussed shortly. Fowler and Dell (2006:34-44) reflect on the framework that Fowler (1981) proposed to understand the conceptualisation of God through the religious and spiritual development of human beings. This framework has also been influenced by the stages as proposed by Jean Piaget and Erick Erikson. It is beneficial for further discussion to look at the first three stages as described by Fowler and Dell (2006:36-39):

- Primal faith (Infancy - 2 years). During this stage, the focus is on the importance of making healthy attachments in learning to trust others. Here Fowler and Dell (2006:37) also refers to Erik Erikson's stage of human development called 'Basic trust vs. Basic mistrust' (Erikson 1963:247)

- Intuitive-projective faith (Toddlerhood - early childhood). Children's imagination is key in responding to experiences when they try to make sense of the '... newness of both everyday reality and the penumbra of mystery that surrounds and pervades it' (Fowler \& Dell 2006:38). Fowler, influenced by Piaget, is of the opinion that these children are not able to distinguish fact from fiction.

- Mythic-Literal faith (Middle childhood and beyond). During this stage, children develop a strong sense of justice and believe that '... goodness is rewarded and badness is punished' (Fowler \& Dell 2006:39). They are able to capture the meaning of life in stories, yet unable to reflect on the bigger picture. Symbolic language is often misunderstood.

\section{The impact of hospitalisation on a child's concept of holiness and God as the Holy One}

It is clear that children's cognitive development has the ability to influence their perception and understanding of God, including the possibility for misconceptions. Adults often want to give their own interpretation of a situation, but they forget that trauma is subjective, and a child can interpret any event as overwhelming and traumatic if they experience fear and do not understand what is happening. Levine and Kline (2007:4) explain that trauma happens in the nervous system of the child and is not embedded in the event itself. Hospitalisation has been described as '... at best a difficult and sometimes traumatic event in the life of a child, especially when the child is seriously ill' (Farrel et al. 2008:261). Levine and Kline (2007) warn that, going to hospital and having an operation has the potential to be traumatic for a child, and explain that:

.... without appropriate support, children do not have the inner resources to comprehend the blinding lights, physical restraints, surgical instruments, masked monsters speaking in garbled language, and drug-induced altered states of consciousness. (pp. 184-185)

They further compare this experience to '... being abducted and tortured by revolting alien giants' (Levine \& Kline 2007:185).

Bull and Gillies (2007:38) quote a 9-year-old girl who expressed the wish to share with God that the hospital '... was scary ... it was like hell'. When I was working with children in an oncology ward a couple of years ago, a volunteer asked the children to make a drawing of their doctor for a project. One 10-year-old boy drew a figure that resembled the devil, complete with horns and a tail, holding a fork in the one hand and a doctor's case in the other. It is quite possible that this boy also gave expression to the feeling he had that the hospital (and everybody associated with it), 'was like hell'.

Nash et al. (2015:17) discuss elements that can cause spiritual pain and distress for children when in hospital, such as invasive and painful procedures; hearing and observing other children in pain that can evoke fear; losing trust in adults and experiencing separation, loss and grief. But it is not only the hospital environment and what is happening to the child that can be traumatic. A child's concept of God and the meaning that they give to illness, suffering and pain can also cause distress. Clutter (2005:368) explains that because of the cognitive development of children they can often harbour an inaccurate perception of God that can cause spiritual pain. This author further clarifies that there might be a discrepancy between the image a child has about God and how they experiences God, as the image of God is often negatively influenced by parents, caregivers and the church. Although the spiritual realm can be a source of hope for children during stressful times, it often contributes to the child's perception that they are being punished by God (Kamper et al. 2010:302). 
It is therefore important to have discussions with children to identify any such distorted images of God.

Other misconceptions that children may have can be because of the fact that they do not understand medical equipment or procedures. A few years ago, a 5-year-old child got very upset after a routine chest X-ray was taken. After careful probing, it became evident that the doctor showed the X-ray to the child and explained all the major organs in the chest. However, this child believed that Jesus was in her heart, and when she could not see Him there, it caused a spiritual crisis, one that she was not willing to share easily out of shame for what it can imply. During another discussion where I explained to a 6-year-old boy what he will experience when going for a minor operation, he started asking questions about where his body will go and when the boy in the pictures I was showing him, will be diseased. It was not until his mother confirmed that his father passed away in the same hospital a few months ago, that I realised this boy thought he was going to die during the operation. His previous experience of a hospital taught him that a hospital is a place where people would go to only when they are dying. The same cognitive thinking occurred in a 5-year-old girl when she thought she was going to be euthanised by her immunisation injection, simply because that was what happened to her dog a few months ago.

Hart and Schneider (1997:267) warn that because of the combination of concrete thinking and the development of a conscience, toddlers and young children often believe they are being punished by their illness for something they did wrong. A 7-year-old once thought she got cancer because God was mad at her for not treating her brother well (Anderson \& Steen 1995:13). I have experienced more than once that a child would plead with me not to perform some procedure, promising that they will behave. Hesch (1987:122) describes more or less the same situation where a small child who was hospitalised for appendicitis, prayed: 'I'm sorry God, for being bad. Please let me go home soon'.

It is clear that, when children are hospitalised, there is the potential of an abundance of misconceptions. However, if children are guided with care and sensitivity to their needs, the hospital experience can have a positive impact on children and enable them to grow stronger and be more able to cope with difficult situations in future.

Nobody wants to address or even think about the purpose of suffering where children are concerned, but it is a topic that should be explored. Parry and Chesler (2005:1055) comment, '... the results suggest that in the aftermath of a trauma such as childhood cancer, many outcomes are possible, including thriving' and Duran (2013) reports on the positive effects of a cancer diagnosis as perceived by childhood cancer survivors, stating that:

.... the findings suggest that illness becomes our best teacher to get to know ourselves at a deeper level and the world in a new dimension with new meaning. Working through an illness brings out our best, teaching us what life is all about. (p. 179)
Spirituality gives meaning and purpose to life, even if a child has been diagnosed with cancer (Hart \& Schneider 1997:263).

Shooter (2012) held interviews with survivors of abuse and reports on their relationship with God. One of the respondents, who survived a concentration camp as a child and later suffered domestic violence in her marriage, is quoted, saying:

When I really didn't know anything about God, He was there, I was his child. I was precious to Him even then, and gradually I've seen glimpses of Him. And you see glimpses particularly when you go through the valleys in life. I've had some fantastic mountain top experiences, but it's in the valley that you really meet God, isn't it? (p. 53)

Hesch (1987:187) concludes that, although illness and suffering should not be seen as inherently good, suffering can teach us to place our trust in God and to know that He is always near, as illness often results in experiencing God in a different way.

\section{Addressing a child's experience of holiness and God as the Holy One in hospital}

In an environment of advanced technology, economic restrictions and viewing patients as customers, nursing care is focussing on physical tasks, resulting in a lack of spiritual care for children in hospital (Elkins \& Cavendish 2004:181). According to Puchalski et al. (2014:642), patients are often seen as '... a disease that needs to be fixed' as speedily and economically as possible, often to the detriment of the mental and spiritual needs of the patient. Limited studies have been done in this area and it is a field waiting to be explored through research. Addressing spirituality with children and their families can be complex and healthcare professionals also expressed the necessity for training in this regard (Llewellyn et al. 2012:232).

The following aspects of spiritual care should receive attention when a child is admitted to hospital. These suggestions are not conclusive, but rather an introduction to a field that is still lying fallow.

\section{Dealing with misconceptions}

As mentioned in the examples above, children often harbour various misconceptions when admitted to hospital and they can also see hospitalisation as a punishment for something they did wrong. Hospitalisation can generate fear in a child, and this can be as a result of actual painful procedures, or because of some misconception with regard to the procedure. Anderson and Steen (1995:13) state that it is important to have a discussion with children and to listen carefully for any indication that there might be some or other misconception so that any pathological beliefs and perceptions can be identified. If children understand the reason for their hospitalisation, and if they can understand that they are not being punished for some wrongdoing, it will assist them in 
their relationship with God and enable them to experience God's presence and the love of others during these difficult times.

\section{Increasing children's understanding of God as the Holy One}

Although a spiritual experience does not necessitate cognitive understanding, it is important to increase a child's understanding of God to further combat misconceptions. Yust (2004:70) explains that religion and religious traditions have a unique language and descriptions that are used within a community that may seem to be unfamiliar to others, and children are usually educated in their family home with regard to these traditions. Assessing a child's understanding and religious language should therefore be regarded as a priority before engaging in the spiritual support of the child to adequately support a child's existing faith as suggested by Clutter (2005:375).

The concreteness of religious rituals makes it valuable in assisting children to understand spiritual issues and can serve to increase their relationship with God. Rituals that the child is familiar with, such as praying, reading Bible stories, anointing with oil, laying on of hands or taking part in Holy Communion, are important in helping children to relate to God and should continue when a child is in hospital. Rituals can be seen as an important way of communicating certain truths to the child (Grossoehme 1999:120) and can also be comforting, reassuring, as well as empowering to children (Nash et al. 2015:129). Prayer plays an important part of the spiritual care of children, especially during stressful times (Hart \& Schneider 1997:268; Nash et al. 2015:133). Anderson and Steen (1995:16) conclude that prayer ' ... build a bridge between children and God'. Grossoehme (1999:67-68) explains the importance of having discussions with children when they are frustrated about prayers that have not been answered and encourages pastoral caregivers to introduce contemplative prayer to children. He explains that contemplative prayer can be seen as 'wasting time' with God, and states that when children pray this way, they can have the experience (even if it is just for a few minutes) of being whole, healthy and peaceful because they are in the presence of God. Emile Durkheim (1915) adds:

The believer who has communicated with his God, is not merely a man who sees new truths of which the unbeliever is ignorant; he is a man who is stronger. He feels within him more force, either to endure the trials of existence, or to conquer them. (p. 416)

Anderson and Steen (1995:16) point out the importance of Bible stories and devotionals in supporting children through stressful times and state that children should be able to relate to and understand the message. When communicating with children about spiritual issues, it is important to use language the children can identify with. Religious language should be:

.... clear enough to be comprehended by young people, rich enough to be meaningful, concrete enough to relate to the world as it is, and critical enough to keep open the dynamics of inquiry and continuing conversation. (Dykstra 1986:182)

\section{Addressing guilt and sanctification}

Feelings of guilt can cause children to feel isolated from God as well as from family members (Grossoehme 1999:43). Children should always be ensured that they did not do anything wrong to cause their illness. In the case where a child misbehaved and caused an accident, they should be carefully guided to ask forgiveness and to forgive themselves, as forgiveness is an important aspect of coping in children dealing with adverse circumstances (Crawford et al. 2006:362). When Millar (2009:160) held interviews with children, it became clear that they trust God to offer forgiveness, as is evident in the following statements made by two children: 'If you do a bad thing, you pray to God and ask for forgiveness' and 'If you don't (confess) you get trapped. If you do pray you will be free'. Clutter (2005:389) states that forgiveness is vital for restoration and peace, and concluded that the experience of forgiveness can be quite powerful for children.

When interacting with a child, attention should be paid to any indication that the child harbours feelings of resentment and anger towards doctors, nurses and other healthcare workers. If this is the case, it is important to ensure that the child understands the reason for their treatment and the procedures that are involved, and that it was not done to punish the child in any way or to hurt the child intentionally. The child should then be carefully guided to forgive the healthcare staff as well. Children have an amazing ability to forgive, as is evident in the following expression by a 9-year-old: 'If my friends hurt me, there is no point getting angry, no point hurting them back, instead we just say sorry and get on with stuff' (Millar 2009:154).

\section{Communicate love}

Field (2015:179) reflects on John Wesley's interpretation of 'holiness as love' and states, '... holiness as love for God and our fellow human beings is rooted in and arises out of God's free love for us as individuals'. Hart and Schneider (1997:270) explored ways of improving the spiritual care of children diagnosed with cancer, and conclude that it is important to nurture a trusting relationship with the child in hospital, marked by sensitivity, a caring approach and acceptance. Chapman and Campbell (1997) propose the following five 'love languages' that can be used to communicate unconditional love to children:

- Physical touch: touch that is appropriate such as stroking a child's hand or rustling his hair is one way of conveying love and care to a child. Anderson and Steen (1995:15) explain the importance of touch, and mention an 18-yearold who was terminally ill and seemed to be depressed. When his nurse offered to rub his back, he accepted, stating that '... she was the first person who had touched him since he had been in the hospital'. Hesch (1987:184) urges pastoral care workers to reach out and touch children, but also point out the importance of getting the child's consent first. This author further concludes that '... touch is reassuring, touch is comforting, touch is affirming; it connotes protection, concern, and good will; touch is loving'. 
- Words of affirmation: Chapman and Campbell (1997:45) emphasise the power of words to communicate love, show affection, encourage and give guidance, and quote the New International Version of Proverbs 18:21, stating that '... the tongue has the power of life and death'.

- Quality time: spending time playing and interacting with children can assist in normalising the hospital environment for children. Godly Play, developed by Berryman (1991:xi), is a program where children can visualise the message of biblical stories in a playful manner. This program successfully enabled children with disabilities to establish relationships and to express spiritual concerns (Eddins, Grogan \& Frick 2014:9) and was also found to have a significant positive effect on the anxiety, depression and spirituality of hospitalised children (Farrel et al. 2008:262, 266).

- Gifts: handing out toys or other small gifts are an important part of communicating love to children, and can even be used to convey a spiritual message. A volunteer once made cards with a glow-in-the-dark Cross on each card that the children could place next to their bed - a visible reminder that Jesus is still with them during the dark hours of the night. Nash et al. (2015:135) mention that families welcomed the gift of a childfriendly prayer rope as a symbol of care, faith and hope.

- Acts of service: the act of visiting and caring for children who are ill, is in itself considered to be an act of service (Chapman \& Campbell 1997:90). Helping children with their homework or meeting their needs in a caring way will also communicate love and affection to these children.

\section{Encouraging compassion for others}

Nash et al. (2015:130) discuss a case study of an 8-year-old boy, who, after receiving guidance to confront his own spiritual wounds after three months in hospital, decided to pray for other sick children as he experienced compassion for other children who were suffering. They further explain that this concern for other children who are suffering is often encountered among hospitalised children. Clutter (2005:388) agrees and suggests that children who experienced some sort of illness are capable of conveying significant messages that can benefit both children and adults. Caring for and helping others are important aspects of nurturing children's spiritual lives, as they help them to feel valuable and enhance their sense of belonging (Baumgartner \& Buchanan 2010:92).

\section{Conclusion}

Children are able to have an understanding of holiness and God as the Holy One. However, misconceptions are common, especially when children are experiencing illness and suffering, and it is therefore crucial that children receive the right guidance and adequate spiritual support when admitted to hospital. But in caring for these children, we can learn more from them on holiness than from anyone else:

For in listening to children, we begin to understand more about the image of God in other human beings, and see more clearly what God wants us to be. Too often we get puffed up with our own sense of self-importance. We want to do big, important things. But nothing is more important than becoming like a little child - wholly dependent on the Lord - and reaching out to other children in his name. (Shelly 1995:3)

\section{Acknowledgements Competing interests}

The author declares that she has no financial or personal relationships which may have inappropriately influenced her in writing this article.

\section{References}

Anderson, B. \& Steen, S., 1995, 'Spiritual care: Reflecting God's love to children', Journal of Christian Nursing 12(2), 12-17, 47. http://dx.doi.org/10.1097/00005217199512020-00005

Baring, R., 2012, 'Children's image of God and their parents: Explorations in children's spirituality', International Journal of Children's Spirituality 17(4), 277-289. http:// dx.doi.org/10.1080/1364436X.2012.746935

Barnes, L.L., Plotnikoff, G.A., Fox, K. \& Pendleton, S., 2000, 'Spirituality, religion, and pediatrics: Intersecting worlds of healing', Pediatrics 106(4), 899-908.

Baumgartner, J.J. \& Buchanan, T.K., 2010, 'Supporting each child's spirit', Young Children 65(2), 90-95.

Berryman, J.W., 1991, Godly play: A way of religious education, Harper Collins, New York.

Berryman, J.W., 2009, Children and the theologians: Clearing the way for grace, Morehouse Publishing, New York.

Bull, A. \& Gillies, M., 2007, 'Spiritual needs of children with complex healthcare needs in the hospital', Paediatric Nursing 19(9), 34-38. http://dx.doi.org/10.7748/ paed.19.9.34.s24

Chapman, G. \& Campbell, R., 1997, The five love languages of children, Northfield Publishing, Chicago, IL.

Clutter, L.B., 2005, 'Spiritual issues in children's health-care settings', in J.A. Rollins, R. Bolig \& C.C. Mahan (eds.), Meeting children's psychosocial needs across the health-care continuum, pp. 351-420, Pro-Ed, Austin.

Crawford, E., O'Dougherty Wright, M. \& Masten, A.S., 2006, 'Resilience and spirituality in youth', in E.C. Roehlkepartain, P.E. King, L. Wagener \& P.L. Benson (eds.), The handbook of spiritual development in childhood and adolescence, pp. 355-370, Sage, Thousand Oaks, CA.

Duran, B., 2013, 'Posttraumatic growth as experienced by childhood cancer survivors and their families', Journal of Pediatric Oncology Nursing 30(4), 179-197. http:// dx.doi.org/10.1177/1043454213487433

Durkheim, E., 1915, The elementary forms of the religious life, transl. J.W. Swain, George Allen \& Unwin, London.

Dykstra, C., 1986, 'Youth and the language of faith', Religious Education 81(2), 163-184. http://dx.doi.org/10.1080/0034408600810202

Eddins, S.L., Grogan, N. \& Frick, B., 2014, 'Healing and belonging: Godly play in pediatric medicine and the theology of disability', Journal of Pastoral Care and Counseling 68(3), 1-12. http://dx.doi.org/10.1177/154230501406800303

Elkins, M. \& Cavendish, R., 2004, 'Developing a plan for pediatric spiritual care', Holistic Nursing Practice 18(4), 179-184. http://dx.doi.org/10.1097/00004650200407000-00002

Erikson, E.H., 1963, Childhood and society, W.W. Norton \& Company, New York.

Farrel, J., Cooper, J.H., Cope, S.B. \& Mathias, L., 2008, 'Godly play: An intervention for improving physical, emotional, and spiritual responses of chronically ill hospitalized children', The Journal of Pastoral Care and Counselling 62(3), 261-271. http://dx.doi.org/10.1177/154230500806200307

Feudtner, C., Haney, J. \& Dimmers, M.A., 2003, 'Spiritual care needs of hospitalized children and their families: A national survey of pastoral care providers perceptions', Pediatrics 111(1), 67-72. http://dx.doi.org/10.1542/peds.111.1.e67

Field, D.N., 2015, 'Holiness, social justice and the mission of the church: John Wesley's insights in contemporary context', Holiness 1(2), 177-198.

Flavell, J.H., 1963, The developmental psychology of Jean Piaget, D. Van Nostrand Company, New York.

Fowler, J.W., 1981, Stages of faith: The psychology of human development and the quest for meaning, Harper \& Row, New York.

Fowler, J.W. \& Dell, M.L., 2006, 'Stages of faith from infancy through adolescence: Reflections on three decades of faith development theory', in E.C. Roehlkepartain, P.E. King, L. Wagener \& P.L. Benson (eds.), The handbook of spiritual development in childhood and adolescence, pp. 34-45, Sage, Thousand Oaks, CA.

Grossoehme, D.H., 1999, The pastoral care of children, Haworth Pastoral Press, New York.

Gundry-Volf, J., 2001, 'The least and the greatest: Children in the New Testament', in M.J. Bunge (ed.), The child in Christian thought, pp. 29-60, William B. Eerdmans, Grand Rapids, MI.

Hart, D. \& Schneider, D., 1997, 'Spiritual care for children with cancer', Seminars in Oncology Nursing 13(4), 263-270. 
Hart, T., 2003, The secret spiritual world of children, New World Library, Novato, CA.

Hesch, J.B., 1987, Clinical pastoral care for hospitalized children and their families, Paulist Press, New York.

James, W. (1902). The varieties of religious experience: A study in human nature, Longman, Green \& Co, New York.

Johnson, C.N. \& Boyatzis, C.J., 2006, 'Cognitive-cultural foundations of spiritual development', in E.C. Roehlkepartain, P.E. King, L. Wagener \& P.L. Benson (eds.), The handbook of spiritual development in childhood and adolescence, pp. 211-223, Sage, Thousand Oaks, CA.

Kamper, R., Van Cleve, L. \& Savedra, M., 2010, 'Children with advanced cancer: Responses to a spiritual quality of life interview', Journal for Specialists in Pediatric Nursing 15(4), 301-306. http://dx.doi.org/10.1111/j.1744-6155.2010.00253.x

Levine, P.A. \& Kline, M., 2007, Trauma through a child's eyes: Awakening the ordinary miracle of healing, North Atlantic Books, Berkeley, CA.

Llewellyn, H., Jones, L., Kelly, P., Barnes, J., O'Gorman, B., Craig, F. et al., 2012 'Experiences of healthcare professionals in the community dealing with the spiritual needs of children and young people with life-threatening and life-limiting conditions and their families: Report of a workshop', BMJ Supportive \& Palliative Care 5, 232-239.

McSherry, W. \& Smith, J., 2007, 'How do children express their spiritual needs?', Paediatric Nursing 19(3), 17-20. http://dx.doi.org/10.7748/paed.19.3.17.s20

Mercer, J.A., 2005, 'Who do you say I am? Children's identities, "Spiritual Capital" and congregational life', Family Ministry 19(4), 11-31.

Millar, S., 2009, 'Forgiveness', in A. Richards \& P. Privett (eds.), Through the eyes of a child: New insights in theology from a child's perspective, pp. 146-164, Church House Publishing, London.

Mountain, V., 2011, 'Four links between child theology and children's spirituality', International Journal of Children's Spirituality 16(3), 261-269. http://dx.doi.org/ 10.1080/1364436X.2011.617729

Nash, P., Darby, K. \& Nash, S., 2015, Spiritual care with sick children and young people, Jessica Kingsley, London.

Nye, R., 2004, 'Christian perspectives on children's spirituality', in D. Ratcliff (ed.) Children's spirituality: Perspectives, research and applications, pp. 90-107, Cascade Books, Eugene, OR.
Oberholzer, A.E., 2016, 'The spiritual needs of a child in hospital: Nurturing the vessel within', Pharos Journal of Theology 97, 1-13.

Oberholzer, A.E., Nel, E., Myburgh, C.P.H. \& Poggenpoel. M., 2011, 'Exploring the needs and resources of children in a haematology-oncology unit', Health SA Gesondheid 16(1), 1-12. http://dx.doi.org/10.4102/hsag.v16i1.565

Osinoiki, O., 2016, The highway of holiness: A close look at holiness for this generation, Booktnago, Bloomington, IN.

Parry, C. \& Chesler, M.A., 2005, 'Thematic evidence of psychosocial thriving in childhood cancer survivors', Qualitative Health Research 15(8), 1055-1073. http://dx.doi.org/10.1177/1049732305277860

Pearson, L.J., 2005, 'Children's hospitalization and other health-care encounters', in J.A. Rollins, R. Bolig \& C.C. Mahan (eds.), Meeting children's psychosocial needs across the health-care continuum, pp. 351-420, Pro-Ed, Austin, TX.

Pretorius, S.P., 2008, 'Understanding spiritual experience in Christian spirituality', in P.G.R. De Villiers, C.E.T. Kourie \& C. Lombaard (eds.), The spirit that empowers: Perspectives on spirituality (Acta Theologica Supplementum 11), pp. 147-165, University of the Free State Press, Bloemfontein.

Puchalski, C.M., Vitillo, R., Hull, S.K. \& Reller, N., 2014, 'Improving the spiritual dimension of whole person care: Reaching national and international consensus', Journal of Palliative Medicine 17(6), 642-656. http://dx.doi.org/10.1089/ jpm.2014.9427

Scarlett, W.G., 2006, Toward a developmental analysis of religious and spiritual development, in E.C. Roehlkepartain, P.E. King, L. Wagener \& P.L. Benson (eds.), The handbook of spiritual development in childhood and adolescence, pp. 21-33, Sage, Thousand Oaks, CA.

Shelly, J.A., 1995, 'Welcoming children', Journal of Christian Nursing 12(2), 3. http:// dx.doi.org/10.1097/00005217-199512020-00001

Shooter, S., 2012, How survivors of abuse relate to God: The authentic spirituality of the annihilated soul, Ashgate Publishing, Surrey.

Spilka, B., Zwartjes, W.J. \& Zwartjes, G.M., 1991, 'The role of religion in coping with childhood cancer', Pastoral Psychology 39(5), 295-303. http://dx.doi. org/10.1007/BF01020701

Yust, K.M., 2004, Real kids, real faith: Practices for nurturing children's spiritual lives, Jossey-Bass, San Francisco, CA. 